\title{
Lymphoplasmacyte-rich meningioma: a case report of a rare neoplasm
}

\author{
Meningeoma rico em linfócitos e plasmócitos: relato de caso de uma rara neoplasia
}

Eduardo Cambruzzi ${ }^{1}$; Thaís Amara da Costa de Souza ${ }^{2}$; Luciano Carvalho Silveira ${ }^{3}$; Carlos Fernando dos Santos Moreira ${ }^{4}$

key words
Pathology
Immunohistochemistry
Central nervous system
Meningioma
Brain tumors

\section{abstract}

Lymphoplasmacyte-rich meningioma (LPM) is a rare variant of meningioma, which is characterized by massive inflammatory cell infiltration and rare meningothelial elements. The authors report the clinicopathological features of a LPM located at the right parietal convexity in a patient with generalized tonic-clonic seizures and paresthesia in the left arm. The surgical specimen consisted of a gray nodule measuring $3.5 \times 3 \times 1.8 \mathrm{~cm}$. At microscopy, a few epithelioid cells associated with numerous lymphocytes/ plasma cells were identified. Positive immunoexpression for epithelial membrane antigen (EMA) and progesterone receptor was found in the epithelioid cells, and positive staining for CD3, CD5 and CD20 in the inflammatory cells. Thus, the diagnosis of LPM was established.

\section{resumo}

O meningeoma rico em linfócitos e plasmócitos (MLP) é uma variante rara de meningeoma, caracterizada por um infiltrado inflamatório massivo e raros elementos meningoteliais. Os autores descrevem as características clinicopatológicas de um MLP localizado na convexidade parietal direita de uma paciente com queixa de crises convulsivas tônico-clônicas generalizadas e parestesia no braço esquerdo. A peça cirúrgica consistia de um nódulo cinzento medindo 3,5 ×3 × 1,8 cm. À microscopia, foram identificadas poucas células epitelioides associadas a numerosos linfócitos e plasmócitos. Imunoexpressão positiva para antígeno da membrana epitelial (EMA) e receptor de progesterona foi encontrada nas células epitelioides, enquanto imunomarcação positiva para CD3, CD5 e CD20 foi identificada nas células inflamatórias. O diagnóstico de MLP foi então estabelecido. unitermos

Patologia

Imuno-histoquímica

Sistema nervoso central

Meningeoma

Tumores cerebrais

\footnotetext{
1. Patologista; pós-doutor em Anatomia Patológica; professor da Universidade Luterana do Brasil (ULBRA).

2. Médica residente em Neurocirurgia no Hospital Cristo Redentor.

3. Médico residente em Neurocirurgia no Hospital Cristo Redentor.

4. Médico residente em Neurocirurgia no Hospital Cristo Redentor.
} 


\section{Introduction}

Meningiomas are common intracranial neoplasms with biological characteristics that distinguish them from most other intracranial tumors. Most occur clinically after the third decade, and its incidence in women exceeds that in men by a ratio of 3:2. Meningiomas are generally well-circumscribed, slowly growing neoplasms that are cured by simple excision when favorably located. Most meningiomas are benign and can be graded into World Health Organization (WHO) grade I. Although meningiomas occur throughout the craniospinal axis, certain sites are clearly favored. These anatomical points includes the parasagittal area within the superior saggital sinus, the cerebral convexities, the wing of the sphenoid bone, the tuberculum sella, the region surrounding the cribriform plate and the foramen magnum, the optic nerve, and the tentorium ${ }^{(3,10,16)}$.

Meningiomas have a wide range of histopathological appearances. Of the 15 subtypes of meningiomas recognized by WHO classification of tumors of the nervous system, the meningothelial, fibrous and transitional meningiomas are by far the most common. Most subtypes share a common clinical behavior, although some subtypes are more likely to recur and follow a more aggressive clinical course. Lymphoplasmacyte-rich meningeoma (LPM) corresponds to a rare subtype of meningioma that shows an extensive chronic infiltrates, often relegating the meningothelial component to the background. This uncommon subtype can be differentiated from others meningeal-based haematological condition ${ }^{(2,3,6,10,12)}$.

The authors report a new case of LPM arising in the cerebral convexity in a female patient, and describe the morphologic and immunohistochemical findings of this uncommon neoplasm.

\section{Case report}

Female patient, 17 years old, was referred to the neurology service featuring episodes of generalized tonicclonic seizures and paresthesia in left arm for six months. The patient reported that the first episode of seizure occurred two years ago. On physical examination, was identified hypoesthesia in the left upper limb. The other systems did not show clinical alterations. The computed tomography (CT) scans (Figure 1) and magnetic resonance imaging (MRI) of the brain showed a nodular lesion in the convexity of the right parietal lobe. The patient was referred for surgical resection of the process, with resolution of neurological symptoms. The surgical specimen consisted of a portion of meninge, which exhibited an ovoid, bocelated, elastic, gray nodule, which measured $3.5 \times 3 \times 1.8 \mathrm{~cm}$. The microscopic examination revealed a proliferation of few neoplastic epithelial cells with eosinophilic cytoplasm and forming solid nests, associated with a dense chronic inflammatory infiltrate rich in lymphocytes and plasma cells (Figures 2 and $\mathbf{3}$ ). The process also showed the formation of lymphoid follicles and foci of fibrosis. Immunohistochemistry revealed positive expression for epithelial membrane antigen (EMA) (Figure 4) and progesterone receptor in the epithelioid cells, and positive staining for CD3, CD5 and CD20 (Figure 5) in the chronic inflammatory cells. A percentage estimated at $1 \%$ for Ki-67 immunoreactivity was found in the epithelial cells. The diagnosis of LPM was then established.

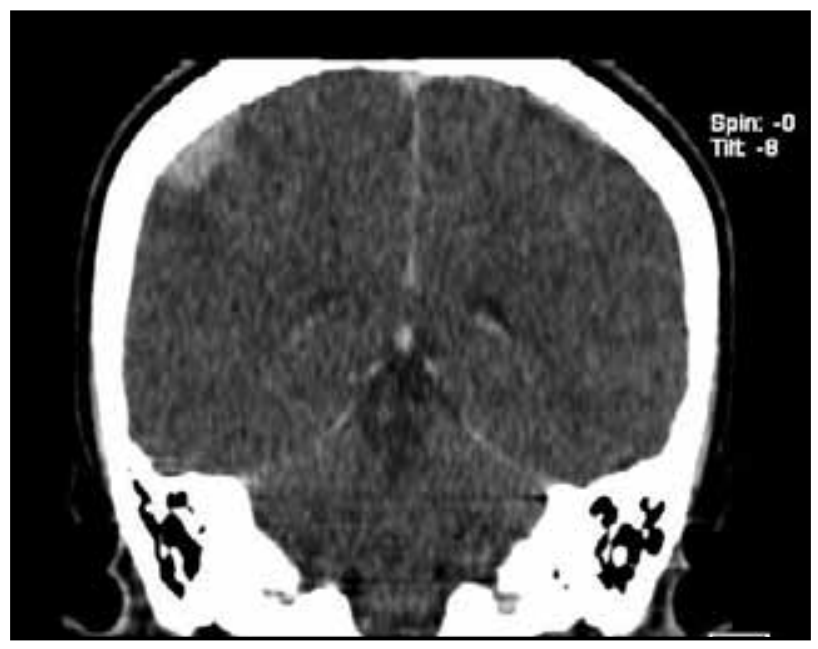

Figure 1 - Preoperative CT scan showing an expansive mass in the right parietal convexity

CT: computed tomography.

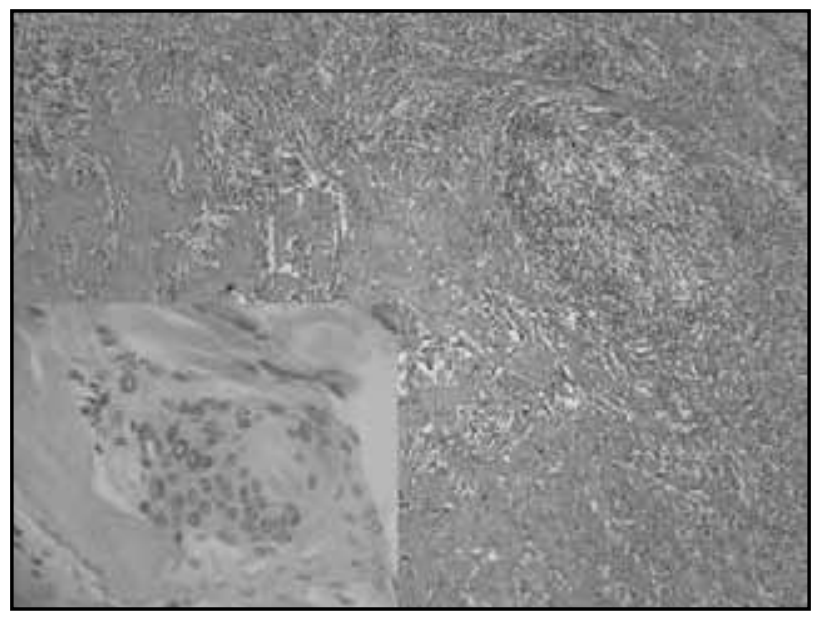

Figure 2 - A dense infiltrate of chronic inflammatory cells obscure the rare neoplastic meningothelial cells (HE 40x)

$H E$ : hematoxylin-eosin. 


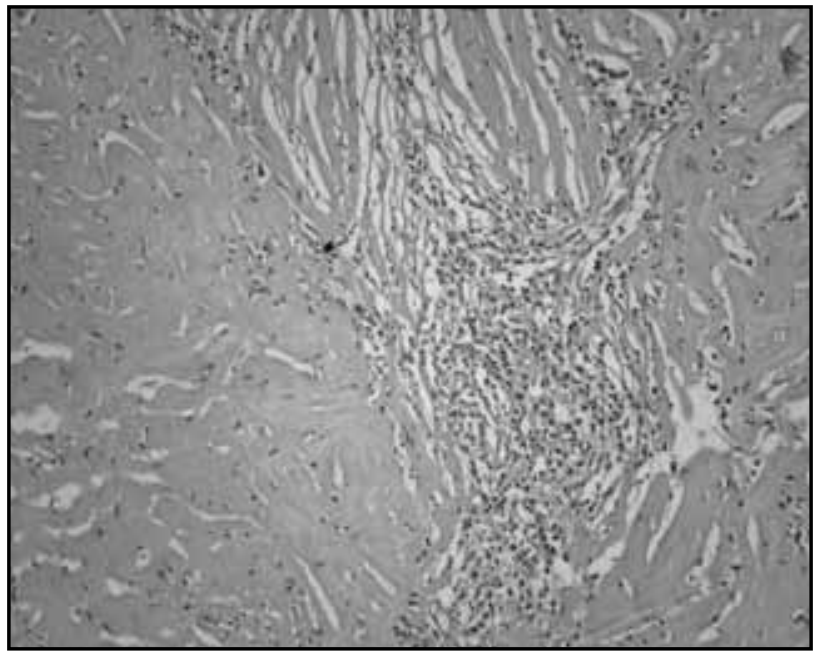

Figure 3 - Small lobules of meningothelial cells between dense areas of fibrosis (HE 100x)

HE: hematoxylin-eosin.

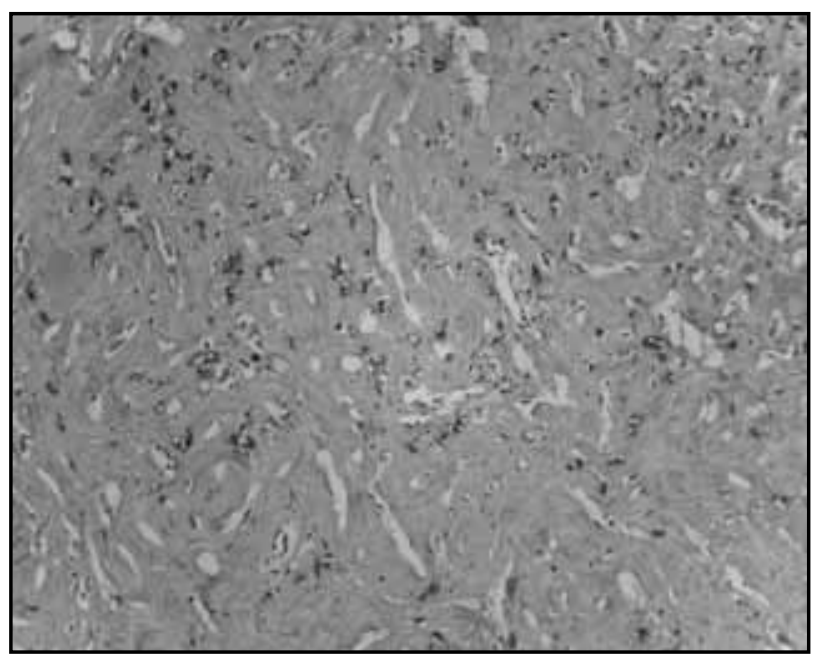

Figure 4 - Epithelioid cells showed positive immunoexpression for EMA, streptavidin-biotin (100x)

EMA: epithelial membrane antigen.

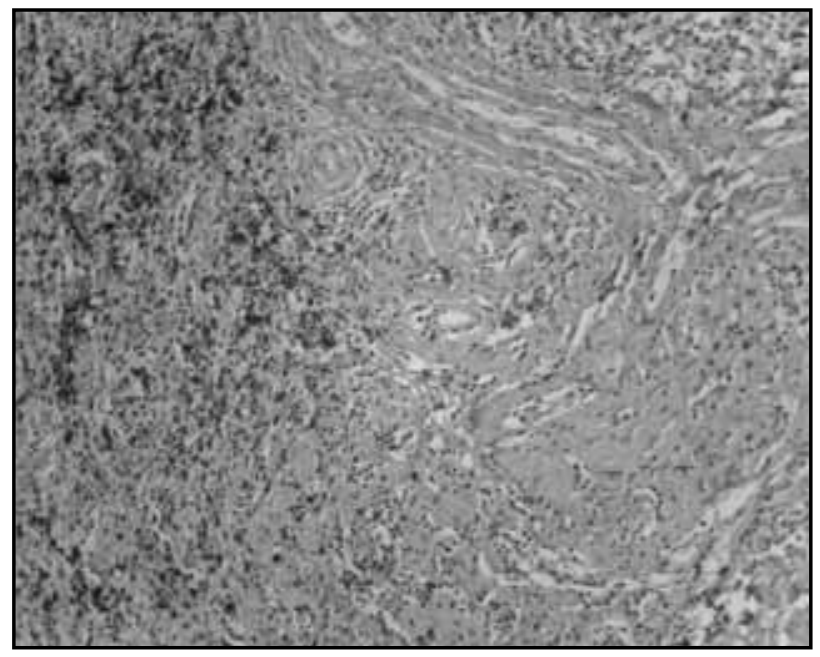

Figure 5 - Inflammatory cells showed positive immunoexpression for CD20, streptavidin-biotin (40x)

\section{Discussion}

Meningiomas are a relatively common neoplasm of the central nervous system that arises from meningothelial (arachnoidal) cells. Although occasional meningiomas occur after cranial radiation or arise in the background of neurofibromatosis 2, most arise from unknown causes. Symptoms are related to the effect of an expanding intracranial mass, including focal neurologic deficts, increased intracranial pressure, and seizures. Intracranial grade I meningiomas are more common in women (ratio of 3 to 2), whereas grade II and grade III lesions predominate in $\operatorname{men}^{(3,6,10,12,16)}$.

LPM is a rare subtype of meningioma recognized by WHO, that shows a pronounced chronic inflammatory response consisting of lymphocytes and plasma cells in varying proportion. They can dominate the lesion and obscure the neoplastic component. Obvious lobules of meningothelial cells may nestle in these inflammatory infiltrates, and a reticulin stain can be helpful by highlighting the nested neoplastic cells. Russel bodies and germinal centers may be found. Bruno et al. suggests that the LPM can be considered an intracranial inflammatory masses rather than a neoplastic lesion, since its biological behavior, immunoprofile and clinical course ${ }^{(2)}$. LPMs are classified into WHO grade I. The tumor may be more common in young patients. The classical appearance of this lesion is a slowly growing, rubbery, well demarcated, rounded nodule with a broad dural attachment, arising over the cerebral convexities, often parasagittal in association with the falx and venous sinus. Other sites include sphenoid ridges, olfactory grooves, parasellar regions, petrous ridges,

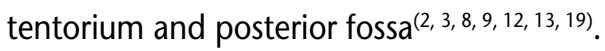

Radiologically, LPMs are usually globular, highly vascular, contrast-enhancing, and dura-based tumors. A wedge-shaped tongue of neoplastic tissue or a cluster of small vessels lying within the angle between the tumor and the attached dura produces a radiographically focus of contrast enhancement known as the "dura tail". Unlike most other central nervous system tumors, which are hyperintense (bright or white) to cortex in T2-weighted images, these meningiomas are usually isointense (gray) or even hypointense (dark) when densely fibrotic and/or calcificated $^{(7,15,16,19)}$.

The tumor exhibits a positive immunoexpression for EMA in a membranous pattern, a diffuse immunoreactivity for vimentin, and in over $50 \%$ of cases can be found a 
positive staining for S-100 protein. Somewhat over half of meningiomas are positive for progesterone receptors, while staining for estrogen receptors is usually negative. Ki-67 immunoexpression is usually low and focal. Since a mononuclear inflammatory is remarkably characteristic of this subtype of meningioma, staining for kappa and lambda lights chains may be needed to ensure the polyclonal nature of the infiltrate and to exclude plasmacytoma. An immunohistochemical panel including the antibodies CD3, CD5, CD10, CD15, CD19, CD20 and CD30 can be necessary to exclude different types of lymphomas. LPMs must be differentiated from other inflammatory pseudoneoplasms. The plasma cell granuloma (PCG) is a term applied to masses, often dura based, that is composed of typical lymphocytes and mature plasma cells, the latter often with Russell bodies, and occasional germinal centers. Nests of reactive meningothelial cells can be found, and extensive hyalinization of fibrous tissue characterizes some examples. The designation inflammatory myofibroblastic pseudotumor has been applied to variants rich in myofibroblasts. PCG is a non-neoplastic condition that exhibits mixed polyclonal production of immunoglobulin (kappa and gamma light chains) on immunostains, associated with positive CD20 and CD5 lymphocytes and CD68 macrophages. Immunohistochemical staining plays an important role to distinguish PCG from LPM, since positive immunoexpression for EMA is usually positive in LPM and negative in PCG. In some circumstances, the distinction between LPM and PCG with reactive meningothelial cells may be very difficult, and the very existence of LPM has been questioned by some ${ }^{(2,16)}$, since reactive meningothelial cells can be encountered between the spindle cell component of PCG (that usually compromises the dura), and the behavior of LPM more closely resemble PCG. LPM is usually an arachonidal lesion in which the neoplastic menigothelial cells are highlighted with reticulin stains. The spindle-cells of PCG are nearly always immunoreactive for smooth muscle actin and vimentin. Rosai-Dorfman is a solitary or multiple, contrast-enhancing lesions, characterized by a lymphoplasmacytic proliferation distinguished by its focal aggregates or larger sheets of pale, often multinucleated, histiocytes, and emperipolesis of lymphocytes. Fibrous connective tissue is present in variable amounts. Immunohistochemically, the process exhibits a striking positivity of the histiocytes for S-100 protein and CD68, and lacks CD1a-positive Langerhans-cells. Castleman disease is a lymphoproliferative disorder, most commonly thought of as a disorder of the mediastinal lymph nodes, with a rich component of plasma cells in the inflammatory background. In this process, the abundant polyclonal plasma cells exhibit positive immunostaining of both kappa- and lamba-chains. There is often a background of predominantly B-cell lymphocytes (CD20 positive) and a minor population of CD3-positive $T$ cells. Idiopathic hypertrophic pachymeningitis is a disease in which there is thickening of the dura, enhancement on appropriate imaging studies, and no microorganisms or other inflammatory disease are recognized ${ }^{(1,2,4,5,11,13,14,16-18)}$.

\section{References}

1. BECKER, I.; ROGGENDORF, W. Immunohistochemical investigation of mononuclear cells infiltrates in meningiomas. Acta Neuropathol, v. 79, p. 211-6, 1989.

2. BRUNO, M. C. et al. Lymphoplasmacyte rich meningioma. A case report and review of the literature. J Neurosurg Sci, v. 48, p. 117-24, 2004.

3. BURGER, P. C.; SCHEITHAUER, B. W.; VOGEL, F. S. In: Intracranial Meninges. Surgical pathology of the nervous system and its coverings. $4^{\text {th }}$ ed. New York: Churchill Livingstone, 2002. p. 49-112.

4. GI, H. et al. Meningioma with hypergammaglobulinemia. Case report. J Neurosurg, v. 73, p. 628-9, 1990.

5. HIRUNWIWATKUL, P.; TROBE, J. D.; MILA, B. Lymphoplasmacyte-rich meningioma mimicking idiopathic hypertrophic pachymeningitis. J Neuroophthalm, v. 27, n. 2, p. 91-4, 2007.
6. KALAMARIDES, M. et al. Identification of a progenitor cell of origin capable of generating diverse meningioma histological subtypes. Oncogene, v. 30, n. 20, p. 2333-44, 2011.

7. KATAYAMA, S. et al. Cystic Iymphoplasmacyte-rich meningioma - case report. Neurol Med Chir, v. 37, n. 3, p. 275-8, 1997.

8. LOH, J. K. et al. Sphenoid ridge lymphoplasmacyte-rich meningioma. J Formos Med Assoc, v. 105, n. 7, p. 594-8, 2006.

9. LOISEAU, H. et al. Lymphoplasmacyte-rich meningioma in a child. Case report. J Neurosurg, v. 83, p. 1075-9, 1995.

10. LOUIS, D. N. et al. In: WHO Classification of Tumors of the Central Nervous System. Meningeal tumors. Lyon: IARC, 2007. p. 163-72.

11. MANABE, M. et al. Extramedullary plasmacytoma of the dura mimicking meningioma. Int J Hematol, v. 91, n. 5, p. 731-2, 2010. 
12. MAWRIN, C.; PERRY, A. Pathological classification and molecular genetics of meningiomas. J Neurooncol, v. 99, n. 3, p. 379-91, 2010.

13. MIZUSHIMA, M. et al. Lymphoplasmacyte-rich meningioma: a case report with histological and immunohistochemical studies. Brain Tumor Pathol, v. 14, n. 10, p. 59-62, 1997.

14. NAKAYAMA, Y. et al. Lymphoplasmacyte-rich meningioma: a convexity mass with regional enhancement in the adjacent brain parenchyma. [Online]. Neuropathology, 2001 Jul. 7. doi: 10.1111/j.1440-1789.2011.01236.x.

15. NOHARA, H. et al. Lymphoplasmacyte-rich meningioma with atypical invasive nature. Neurol Med Chir, v. 47, p. 32-5, 2007.
16. SCHEITHAUER, B. W.; BURGER, P. C. In: Tumors of the central nervous system (AFIP Atlas of tumor pathology). Meningioma. Series 4, fascicle 7. Washington: ARP/ AFIP, 2007. p. 331-62.

17. TRIANA-PÉREZ, A. B. et al. Isolated intracranial RosaiDorfman disease: a case report and literature review. Neurocirugia (Astur), v. 22, n. 3, p. 255-60, 2001.

18. YAMAKI, T. et al. Lymphoplasmacyte-rich meningioma with clinical resemblance to inflammatory pseudotumor. Report of two cases. J Neurosurg, v. 86, n. 5, p. 898904, 1997.

19. YONEYAMA, T. et al. Lymphoplasmacyte-rich meningioma: a report of three cases and a review of the literature. No Shinkei Geka, v. 27, n. 4, p. 383-9, 1999. 